600

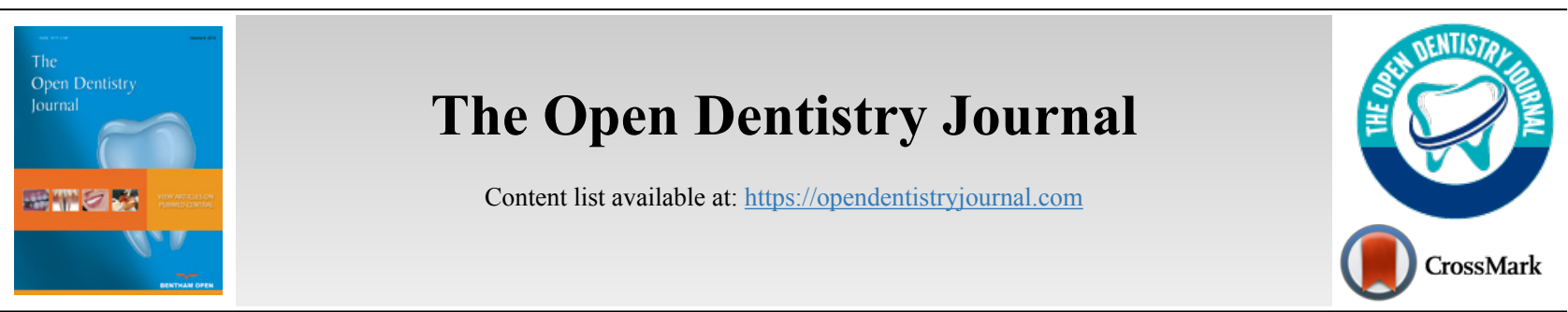

RESEARCH ARTICLE

\title{
Effect of Adhesive Gap Setting on Fracture Resistance of All-ceramic Crowns
}

\author{
Mohammed Zahran ${ }^{1, *}$ \\ 'Department of Oral and Maxillofacial Prosthodontics, King Abdulaziz University, Faculty of Dentistry, Jeddah, Saudi Arabia
}

\begin{abstract}
:
Background:

Several factors might affect the fracture resistance of all-ceramic crowns, including cement thickness.

Aim:

To evaluate the influence of cement thickness on the fracture resistance.

Objective:

To determine the effect of varying the adhesive gap thickness on the fracture loads of all-ceramic CEREC 3D molar crowns.

Methods:

Standardized prepared epoxy resin molar dies (Viade Inc.) were fabricated. A standard molar crown was designed using a CEREC 3D machine (Sirona Dental Systems). Twenty-four crowns were milled from Vita Mark II blocks (Vita Zahnfabrik), using adhesive gap settings of 30, 60 and $90 \mu \mathrm{m}(\mathrm{n}=8)$. A dual-cure resin cement (PanaviaF 2.0, Kuraray) was used to cement the crowns to their respective dies, following manufacturer's recommendation. After 1 week of storage in distilled water at $37^{\circ} \mathrm{C}$, each crown was loaded in compression until complete failure in a universal testing machine (Instron 8501) and fracture loads $(\mathrm{N})$ were recorded. Fractured specimens were sectioned to determine cement thickness. Sections were examined using a traveling light microscope to measure cement thickness. Data were statistically analyzed using one-way ANOVA test and Pearson's correlation at $(\alpha=0.05)$.
\end{abstract}

Results:

The mean fracture loads and standard deviation values in $\mathrm{N}$ were $1,267.57$ (122.82), 1,225.20 (179.46) and 1,180.76 (161.77) for the crowns with 30,60 and $90 \mu \mathrm{m}$, respectively. ANOVA indicated no significant differences among mean fracture strength values $(p=0.55)$. All crowns failed in a catastrophic mode and were not repairable.

\section{Conclusions:}

Adhesive cement gap as achieved with three CEREC 3D settings from 30 to $90 \mu \mathrm{m}$ had no significant effect on fracture strength of crowns made from Vita Mark II blocks.

Keywords: Crowns, Ceramics, Resin cements, Fracture resistance, Cement thickness, CEREC 3D.

\begin{tabular}{|l|l|l|l}
\hline Article History & Received: June 04, 2020 & Revised: September 30, 2020 & Accepted: October 13, 2020
\end{tabular}

\section{INTRODUCTION}

The growing demand for esthetics in combination with health and environmental concerns about some metallic restorations stimulated the profession to explore and consider metal-free tooth-colored alternatives. However, all-ceramic restorations are subject to fracture during function especially in

\footnotetext{
* Address correspondence to this author at the Department of Oral and Maxillofacial Prosthodontics, King Abdulaziz University, Faculty of Dentistry, Jeddah, Saudi Arabia; E-mail: mzahran@kau.edu.sa
}

the posterior area. Several factors might influence the fracture resistance of all-ceramic crowns in-vivo. These factors can be divided into the following: factors related to the restoration (restoration geometry and thickness, material composition, processing, finishing and polishing and internal adaptation of the restoration), [1 - 6] factors related to the supporting structure (modulus of elasticity, and preparation shape, dimensions and geometry) [7 - 10], and factors related to the cementation (cement thickness, mechanical properties of the cement, adhesion mechanism and efficacy of the bond of the 
cement) $[10$ - 12]. Effect of cement thickness on fracture strength of ceramic restorations was studied on bilayer specimens and on restorations with real dimensions [12 - 17]. The methodology and results of these studies are summarized in (Table 1).

Till the introduction of Computer-aided Designing/ Computer-aided Manufacturing (CAD/CAM) technology, the only options available for controlling the cement thickness were controlling the thickness of the die spacer paint, either by controlling the number of application or using materials with low film thickness [18], or controlling the thickness of the foil layer/s which are used for the production of porcelain jacket crowns [12]. Unfortunately, both methods are neither accurate nor precise. Currently, most CAD/CAM systems give the option to control the adhesive gap setting which is hypothesized to affect the cement thickness.

The objective of the present study was to compare the fracture load values of all-ceramic crowns made using three adhesive gap settings utilizing CAD/CAM CEREC-3D technology. The null hypothesis of this in-vitro study was that there is no significant difference in the fracture strength among the feldspathic crowns made with three different adhesive gap settings.

\section{MATERIALS AND METHODS}

The Sample size was calculated using $\mathrm{G}^{*}$ power software (version 3.1) at $(\alpha=0.05, \beta=0.1$, Effect size $=0.8)$ yielding a total sample size equal to 24 [19]. The effect size was calculated using the fracture load data reported previously for monolithic all-ceramic crowns fabricated with similar dimensions from the same material [20].

Twenty-four prepared replicas for $1^{\text {st }}$ mandibular molar were fabricated using a highly-filled epoxy resin (Viade Products Inc. Camarillo, CA, USA), which has an elastic modulus comparable to that of human dentin and responded to $34 \%$ phosphoric acid etching with a formation of surface microroughness [21]. The epoxy replicas were duplicated from a master ivorine $1^{\text {st }}$ mandibular molar die that was prepared to receive all-ceramic crown with $1.5 \mathrm{~mm}$ occlusal reduction, 1 $\mathrm{mm}$ minimum axial reduction, 6 to $8^{\circ}$ total occlusal convergence, $1 \mathrm{~mm}$ wide circumferential shoulder, two planes facial and lingual reduction and smooth line angles. A digital caliper (Mitutoyo Corporation, Tokyo, Japan) was used to verify that the buccolingual and mesiodistal dimensions of the replicas. These measurements showed a low variability of about 10 to $20 \mu \mathrm{m}$ [20].

The replicas were positioned in a typodont with mesial and distal ivorine teeth. Then, CEREC 3 intraoral camera was used to acquire an optical impression for the prepared replica and adjacent teeth using with a thin layer of titanium oxide as an optical reflective medium (Vita Zahnfabrik). Twenty-four monolithic crowns were designed following the correlation mode (to correlate the designed crown's anatomy to an artificial unprepared mandibular molar) using the CEREC software (Version 2.40 R1800; Sirona Dental Systems GmbH, Bensheim, Germany). The unprepared artificial tooth was adjusted in the central fossa to receive a $3 \mathrm{~mm}$ loading ball.

All crowns were made using the CEREC 3 milling unit (serial number 02527) from feldspathic blocks (Vita Mark II, shade A 3.5 on Vitapan classic, $14 \mathrm{~mm}$ long; Vita Zahnfabrik). The crowns were milled using $1.6 \mathrm{~mm}$ cylindrical and coneshaped diamonds. Cutting diamonds were changed after milling eight crowns followed by the milling unit was calibrated. The crowns were divided equally into 3 groups $(\mathrm{n}=8)$ using 3 adhesive gap settings (30,60 and $90 \mu \mathrm{m})$. The following milling parameters were used: a spacer setting of 20 $\mu \mathrm{m}$, margin thickness of $0 \mu \mathrm{m}$, and minimum thickness occlusal of 1,500 $\mu \mathrm{m}$. After milling, Akzent glazing kit (Vita Zahnfabrik) was used to glaze all crowns according to the manufacturer's instructions.

All crowns thicknesses at the central fossae were measured to verify the minimal occlusal measurement of $1.5 \mathrm{~mm}$ using a calliper (Buffalo Dental Manufacturing Co., Syosset, NY, USA). A digital caliper (Mitutoyo Corporation) was used to measure the mesiodistal and buccolingual dimensions at the height of contour. Independent t-test did not reveal any statistically significant difference among the measured dimension for the 3 experimental groups [20].

The intaglio surfaces of crowns were etched with $9.6 \%$ hydrofluoric acid gel (Pulpdent Corporation, Watertown, MA, USA) according to manufacturer's recommendation. The etched surface was sprayed with water, cleaned in ultrasonic water bath for 60 seconds. The prepared surfaces of teeth replicas were treated using $40 \%$ phosphoric acid etching gel (Kuraray America Inc., New York, NY, USA) for 60 seconds, rinsed using water spray and dried with compressed oil-free air. A bonding/silane coupling agent (Clearfil SE bond/Porcelain Bond Activator, Kuraray America Inc.) was applied to the intaglio surface of the crowns following the manufacturer's instructions. A dual-cure resin cement (Panavia F 2, Kuraray America Inc.) was used to cement the crowns to their respected prepared replicas following the manufacturer's recommendation. The crowns were firstly seated using finger pressure, followed by removal of excess cement and application of air sealing gel (Oxyguard, Kuraray America Inc.) margins of the crowns for 3 minutes. Next, a static load of $22 \mathrm{~N}$ was applied to the crowns for 5 minutes [22]. Then, each crown surface was light-cured (Optilux 501, Kerr Demetron, Danbury, CT, USA) for 20 seconds. One hour after cementation, all crowns were stored in distilled water at $37{ }^{\circ} \mathrm{C}$ for 1 week. Tables $\mathbf{1}$ and $\mathbf{2}$ lists the materials used and some of their physical properties. 
Table 1. Studies that evaluated the effect of the cement thickness on the fracture load of bilayer or crown specimens

\begin{tabular}{|c|c|c|c|c|c|}
\hline Author (Year) & Samples & Ceramic Material & $\begin{array}{l}\text { Cement } \\
\text { Thickness }\end{array}$ & Supporting Structure & Conclusion \\
\hline $\begin{array}{c}\text { Scherrer (1994) } \\
{[13]}\end{array}$ & Bilayer specimens & $\begin{array}{c}\text { Machinable glass ceramic (2 } \\
\mathrm{mm} \text { in thickness) }\end{array}$ & $\begin{array}{c}\text { Ranging between } \\
26 \text { to } 297 \\
\text { microns }\end{array}$ & $\begin{array}{l}\text { Chemical-cured } \\
\text { composite }\end{array}$ & $\begin{array}{l}\text { A gradual decrease of the } \\
\text { fracture load was noticed, that } \\
\text { became statistically significant } \\
\text { at a cement thickness of } 300 \\
\text { microns or more. }\end{array}$ \\
\hline $\begin{array}{c}\text { Tuntiprawon } \\
\text { (1995) [12] }\end{array}$ & $\begin{array}{l}\text { Maxillary central } \\
\text { incisor Porcelain } \\
\text { jacket crowns }\end{array}$ & Feldspathic porcelain & $\begin{array}{l}\text { Ranging between } \\
73 \text { to } 122 \mu \mathrm{m}\end{array}$ & $\begin{array}{c}\text { Cobalt-chromium metal } \\
\text { die }\end{array}$ & $\begin{array}{l}\text { Increasing the cement thickness } \\
\text { resulted in reduced the fracture } \\
\text { load of the crowns. }\end{array}$ \\
\hline Prakki (2007) [14] & Bilayer specimens & $\begin{array}{l}\text { Feldspathic ceramic ( } 1 \text { or } 2 \\
\text { mm in thickness) }\end{array}$ & $\begin{array}{c}100,200 \text { and } 300 \\
\mu \mathrm{m}\end{array}$ & Bovine dentin & $\begin{array}{l}\text { For } 1 \mathrm{~mm} \text { ceramic thickness: } \\
\text { Higher cement film thickness } \\
\text { resulted in increased fracture } \\
\text { load. } \\
2 \text { mm ceramic thickness: cement } \\
\text { thickness has no effect. }\end{array}$ \\
\hline May (2012) & $\begin{array}{l}\text { Non anatomical } \\
\text { Crowns }\end{array}$ & Feldspathic ceramic & $\begin{array}{c}50,100,300 \text { and } \\
500 \mu \mathrm{m}\end{array}$ & $\begin{array}{l}\text { A woven glass-filled } \\
\text { epoxy resin }\end{array}$ & $\begin{array}{l}\text { Gradual reduction in the fracture } \\
\text { load with the increase in } \\
\text { thickness and }\end{array}$ \\
\hline $\begin{array}{c}\text { Rojpaibool (2017) } \\
{[15]}\end{array}$ & Bilayer specimens & $\begin{array}{l}\text { Lithium Disilicate ceramic (1 } \\
\mathrm{mm} \text { in thickness) }\end{array}$ & 100 and $300 \mu \mathrm{m}$ & Enamel or dentin & $\begin{array}{l}\text { Increasing cement thickness } \\
\text { resulted in reduction of the } \\
\text { fracture load }\end{array}$ \\
\hline $\begin{array}{c}\text { Sagsoz and } \\
\text { Yanıkoglu (2018) } \\
{[17]}\end{array}$ & $\begin{array}{l}\text { Maxillary } \\
\text { premolar } \\
\text { machinable } \\
\text { crowns }\end{array}$ & $\begin{array}{c}\text { Resin nanoceramic, } \\
\text { feldspathic glass ceramic, } \\
\text { lithium disilicate, and leucite- } \\
\text { reinforced ceramics }\end{array}$ & $\begin{array}{c}30,90, \text { and } 150 \\
\mu \mathrm{m}\end{array}$ & Epoxy resin replicas & $\begin{array}{l}\text { Cement thickness has no effect } \\
\text { on the fracture load }\end{array}$ \\
\hline
\end{tabular}

Table 2. Physical properties of materials used in the study

\begin{tabular}{|c|c|c|c|c|}
\hline Material & \begin{tabular}{|c|}
$\begin{array}{c}\text { Elastic Modulus } \\
\text { (GPa) }\end{array}$ \\
\end{tabular} & $\begin{array}{l}\text { Coefficient of Thermal Expansion } \\
\qquad\left(10^{-6} \cdot \mathrm{K}^{-1}\right)\end{array}$ & \begin{tabular}{|} 
Flexure Strength \\
(MPa)
\end{tabular} & $\begin{array}{c}\text { Fracture Toughness } \\
\left(\mathrm{MPa} * \mathrm{~m}^{1 / 2}\right)\end{array}$ \\
\hline $\begin{array}{c}\text { Vita Mark II } \\
\text { (Vita Zahnfabrik) }\end{array}$ & $70.6^{a}$ & $8.6^{b}$ & $103^{c}$ & $1.26^{\mathrm{d}}$ \\
\hline $\begin{array}{c}\text { Panavia F } 2.0 \\
\text { (Kuraray America Inc.) }\end{array}$ & $9.6^{\mathrm{e}}$ & - & $79^{e}$ & - \\
\hline $\begin{array}{c}\text { Epoxy resin die material } \\
\text { (Viade Products Inc.) }\end{array}$ & $12.9^{\mathrm{f}}$ & - & - & - \\
\hline
\end{tabular}

a) Data from Trindade et al. [44]

b) Data from Charlton et al. [45]

c) Data from Bindl et al. [46]

d) Data from Thompson et al. [47]

e) Manufacturer's data

f) Neiva et al. [21]

The dimension from the occlusal surface of the crown to the apical surface of the replica before and after cementation was measured for each sample using a digital calliper (Mitutoyo Corporation) to ensure the crown seating [20]. A threshold of $50 \mu \mathrm{m}$ was set for the differences between the 2 measurements. None of the samples were rejected for this reason.

All cemented samples were mounted in resin material block (SR Ivolen, Ivoclar Vivadent, Schaan, Liechtenstein) with dimensions matching the loading jig attachment. Each crown was uniaxially-loaded with a 3-mm diameter stainless steel ball at the central fossa in a universal testing machine (Instron 8501, Instron, Canton, MA, USA). Loading was conducted at cross head speed of $1 \mathrm{~mm} /$ minute in distilled water at room temperature. The load-displacement data were imported to a software program (Microsoft Office Excel,
Redmond, WA, USA) and load-displacement curves were generated. Load-displacement curves were analyzed, and the first drop in the curve was identified and the corresponding load $(\mathrm{N})$ was recorded as load at failure.

All crowns were sectioned mesiodistally at the central fossa. Then, the cement layer thickness was measured using a travelling microscope (Mitutoyo Corporation) at three occlusal points (at the middle and near the two occluso-axial line angles). These measurements were averaged for each crown. Two samples of each group were selected for Scanning Electron Microscopy (SEM) examination. The sections from these samples were sputter-coated with $7 \mathrm{~nm}$ of platinum in Polaron E5100 coating unit (Polaron Equipment Ltd., Bedford, UK) and examined using SEM (Hitachi S-2500, Hitachi, Mito City, Japan).

The data was analyzed using a Statistical Package for the 
Social Sciences (SPSS, Version 23, SPSS Inc., IBM, Somers, New York, USA). Both fracture load and cement thickness data were normally distributed; thus parametric tests were selected. The mean fracture loads and cement thickness were compared among the groups using one-way analysis of variance (ANOVA), followed by post-hoc Tukey's test (when appropriate). The association between the fracture load and cement thickness was assessed using Pearson's correlation. All statistical tests performed at a significant level of 0.05 and were two-tailed.

\section{RESULTS}

Mean fracture loads and standard deviations values in $\mathrm{N}$ were $1267.57( \pm 122.82), 1225.20( \pm 179.46)$ and 1180.76
$( \pm 161.77)$ for the crowns with 30,60 and $90 \mu \mathrm{m}$ adhesive gap setting, respectively (Fig. 1). One-way ANOVA revealed no statistically significant difference between the mean fracture loads of the 3 groups $(P=0.551)$. The mean cement thickness and standard deviation values in $\mu \mathrm{m}$ were $260.9( \pm 39.6), 276.4$ $( \pm 28.4)$ and $322( \pm 31.1)$ for the crowns with 30,60 and $90 \mu \mathrm{m}$ adhesive gap setting, respectively (Fig. 2). One-way ANOVA revealed a statistically significant difference between the mean cement thickness of the 3 groups $(P=0.004)$. Post-hoc Tukey's test showed significantly higher cement thickness for the group with $90 \mu \mathrm{m}$ adhesive gap setting in comparison to the other 2 groups. Pearson's correlation revealed no statistically significant correlation between fracture load and the cement thickness $(\mathrm{r}=-0.357, P=0.086)$.

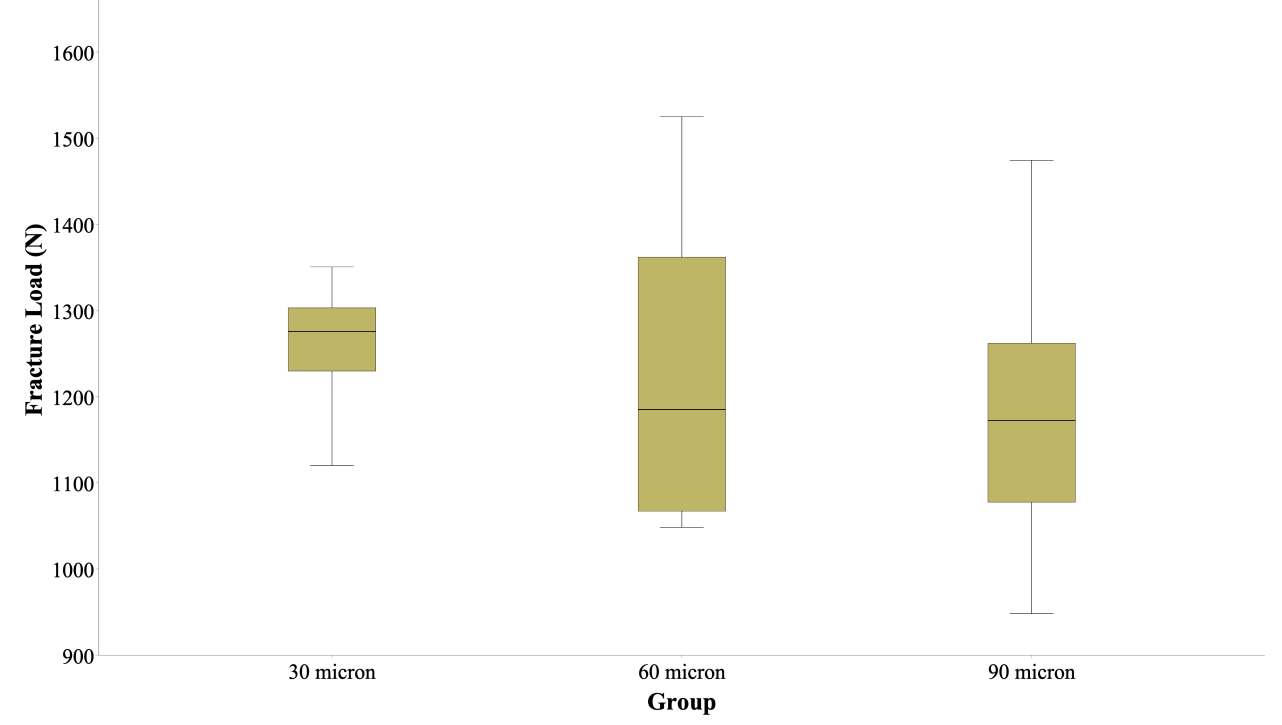

Fig. (1). Box plot graph showing the fracture load (N) for different groups based on the adhesive gap setting.

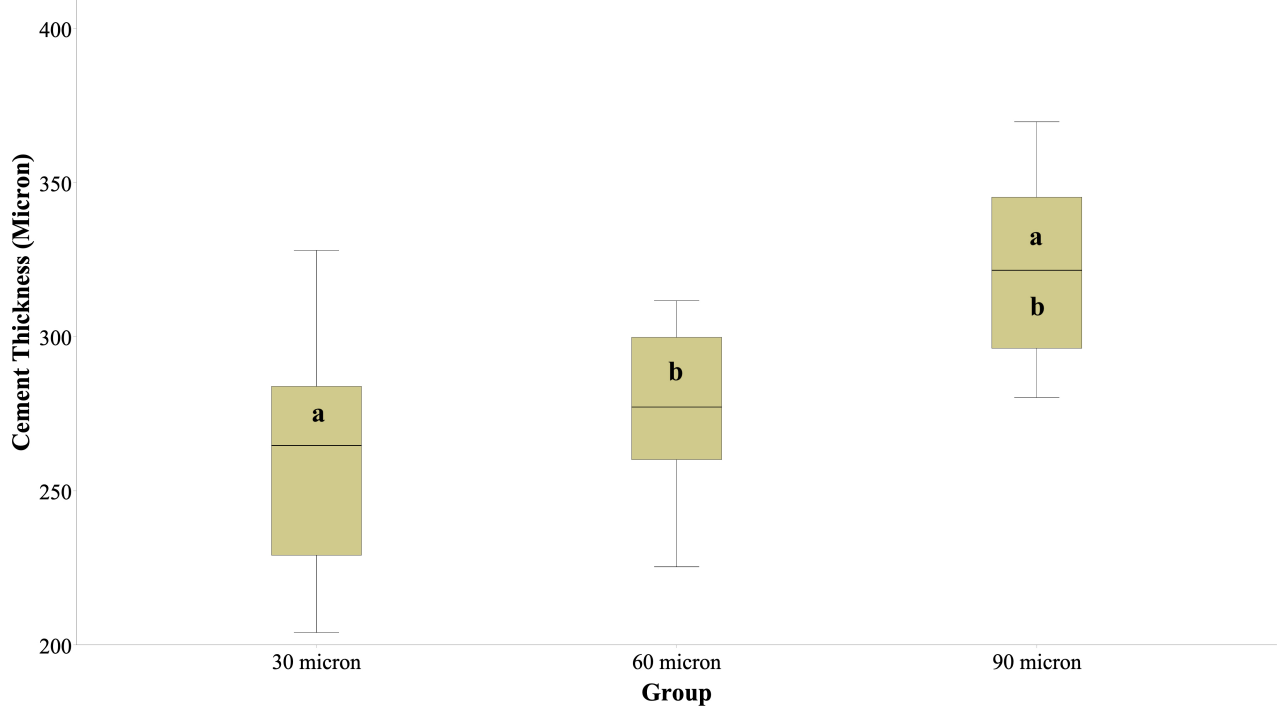

Fig. (2). Box plot graph showing cement thickness (micron) for different groups based on the adhesive gap setting (similar letters indicate statistically significant difference between the groups). 
All crowns failed catastrophically and were not repairable. All fractures were confined to the ceramic material and none of them progressed to the die material. Visual examination revealed that failure originated in the contact area as a cone crack and propagated within the ceramic material till at reached the cement layer (Fig. 3). All the samples showed delamination of part of the crown at the cement interface with the other part still attached to the die material. Some large voids were noticed in the cement layer occlusally (Fig. 4). SEM images showed a homogenous ceramic structure with voids within the cement layer and adequate adaptation of the cement at the interfaces with the die and ceramic materials. Measuring the cement thickness from the SEM images revealed non-uniform thickness with higher thicknesses at the occlusal surface in comparison to the axial surfaces (Fig. 5).

\section{DISCUSSION}

This study failed to prove the alternative hypothesis and accepted the null hypothesis that there is no statistically significant difference between the mean fracture load values for the groups with different adhesive gap settings.

The present study followed the recommendations described by Kelly to achieve a clinically-relevant in-vitro load-to-failure test for all-ceramic restorations, including using a die material with elastic modulus matching the dentin, preparing the teeth according to clinical guidelines, using crowns with clinicallyrelevant dimensions and using a reliable, commonly-used luting cement [23]. Epoxy dies were used to avoid the variability that can be encountered with natural teeth.

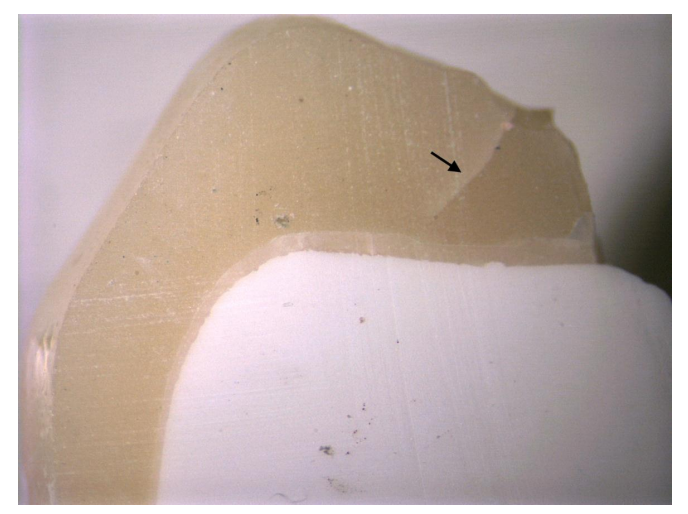

Fig. (3). Microscopic image (2.5x magnification) showing cone crack (arrow) starting at the loading area which propagates till cement layer.

The use of 3-mm stainless-steel ball in the present study is expected to increase the contact pressure within the crowns compared to the clinical contact pressure. Several factors might influence the contact pressure, including the radius of the loading ball and the ratio of the elastic moduli of the dental porcelain and the loading ball [24]. Alternative approach would be to use a tin sheet as a stress breaker between the load applicator and crown, a loading ball with a lower modulus of elasticity or a stainless-steel loading stylus with its end machined to a curvature corresponding to $40-50 \mathrm{~mm}$ diameter to induce clinically relevant contact pressure [23]. The contact pressure employed in this study, however, should not affect the comparison between the groups since all groups were treated equally. It has to be emphasized that the fracture load data reported in the current study should not be considered as "absolute" values and extrapolating these in-vitro data to the clinical performance must be considered cautiously and within the limitation of the study [25].

The fracture strength of Vita Mark II molar crowns was reported previously in the literature with a reported range between 600 and $3000 \mathrm{~N}$ [5, 26 - 28]. The mean fracture load of Vita Mark II crowns in the present study ranged between 1182 and $1267 \mathrm{~N}$, which falls within the previously reported range. As expected for monolithic all-ceramic crowns, all Vita Mark II crowns fractured catastrophically, involving the whole crown thickness [29].

The effect of the cement thickness on fracture resistance was evaluated in several studies as shown in Table 1. These studies differ in terms of the tested materials and methodology. Four of these studies reported a significant negative relationship between the cement thickness and fracture resistance, while one study reported a positive relationship and one study reported no significant association between the two variables. It has to be emphasized that the cement thickness ranges and measurement location varied between the studies. Generally, the studies which reported a significant negative relationship used wide range of thicknesses from $100 \mu \mathrm{m}$ or below to $300 \mu \mathrm{m}$ or above. Reduction in fracture resistance was noticed for the samples with cement thicknesses larger than $300 \mu \mathrm{m}$. Similar to the present study, Sagsoz and Yanıkoglu [17] reported no difference in the mean fracture load for crowns made with different adhesive gap settings ranging between 30 and $150 \mu \mathrm{m}$ without measuring the actual cement thickness.

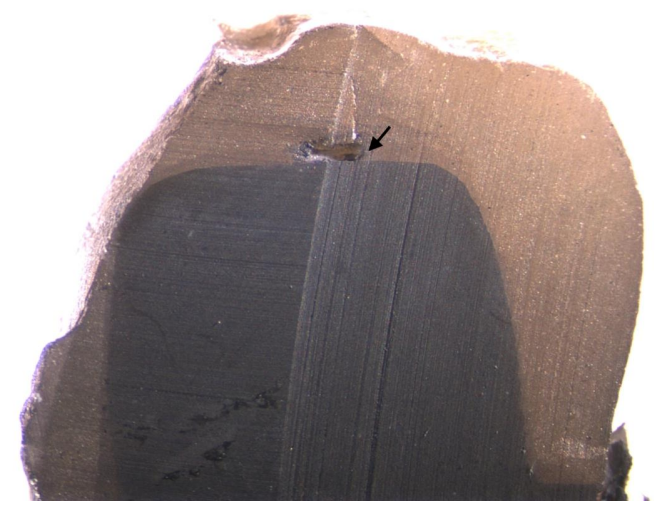

Fig. (4). Microscopic image (2.5x magnification) showing voids (arrow) within the cement layer. 

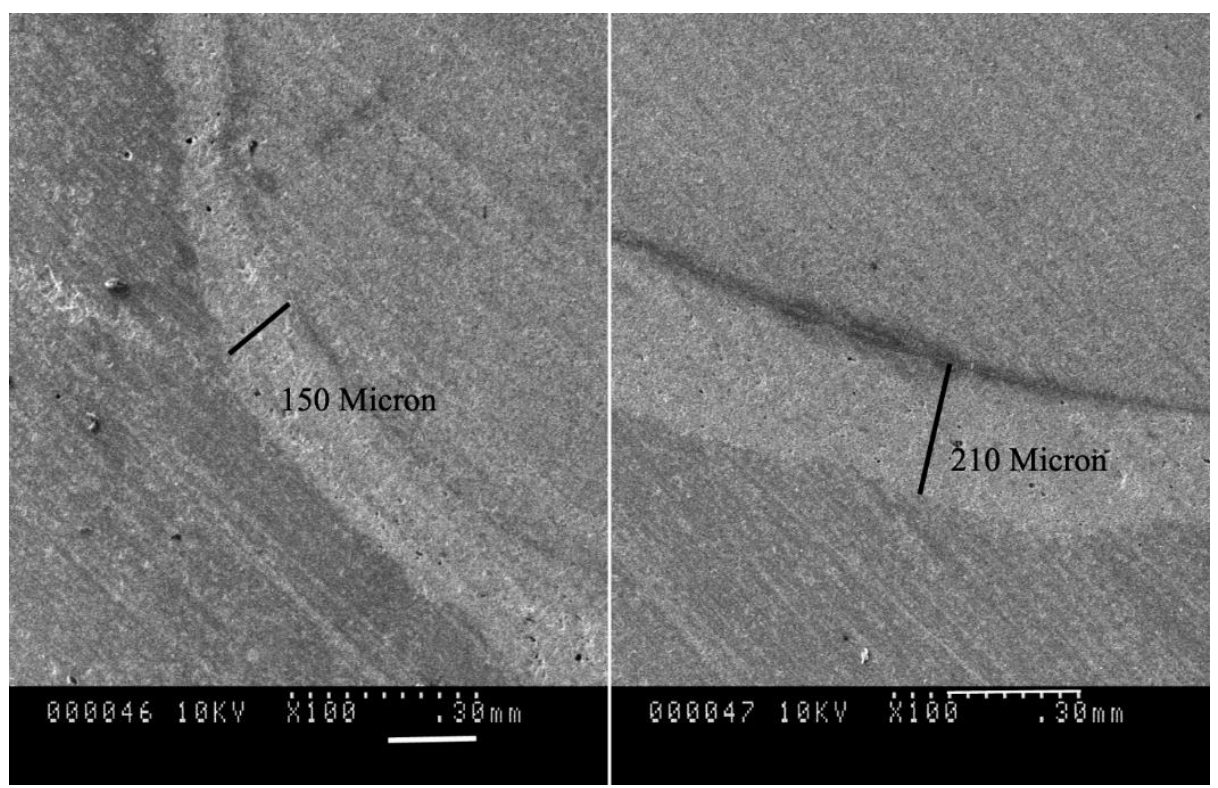

Fig. (5). SEM image showing the non-uniform distribution of the cement thickness at the axial surface (left) and occlusally (right).

It is apparent that the cement thickness is guided by the available gap between the crown and the prepared abutment. Several factors have been identified to affect the internal adaptation of the machinable all-ceramic crowns, including the angle of convergence, luting adhesive gap, luting cement composition and physical properties, occlusal anatomy, margin design and the scanning device technology [30 - 39]. It is obvious from the result of the present study that the adhesive gap setting does not reflect the actual cement thickness. This can be attributed to the acquisition and milling unit limitations. The cement thickness for the $60 \mu \mathrm{m}$ group falls within the previously reported by Zeltner et al. in which bluecam was used to scan preparation and crowns were milled using similar setting used in the current study [36]. Other studies reported lower mean thickness using bluecam and omincam with adhesive gap setting of 60,70 and $80 \mu \mathrm{m}[32,33,40]$. This can be attributed to the improvements in acquisition and milling devices. It worth mentioning that comparing the results of the present study to previous studies should be done with caution due to the differences in the methodology and acquisition and milling devices used. Interestingly, a recent systematic review revealed no significant effect of the impression technique (conventional versus digital) on the internal adaptation of fullcoverage fixed restorations [41].

Rekow et al. [42] conducted factorial analysis of some variables influencing stresses in all-ceramic crowns using finite element analysis. They studied the effect of seven factors (crown material, crown thickness, cuspal inclination, cement elastic modulus, cement thickness, supporting tooth core, and location of occlusal loading). 80 and $100 \mu \mathrm{m}$ cement thicknesses were used. Cement modulus of elasticity and thickness accounted for only $5.5 \%$ and $1.4 \%$ of the variability in the principal stresses in the crown, respectively. These findings are in agreement with the present study. The higher mean cement thickness reported for different groups in the present study, which ranges between 260 and $322 \mu \mathrm{m}$, is not expected to change principal stresses within the crowns significantly. It seems that achieving cement thickness below $100 \mu \mathrm{m}$ occlusally is a challenging task. Pilo and Cardash evaluated the cement thickness under metal-ceramic crowns cemented using zinc phosphate cement to extracted teeth due to periodontal issues and reported occlusal cement thickness of $310 \mu \mathrm{m}$ [43]. Zeltner et al. [36] compared the internal adaptation of machined crowns using the digital workflow to crowns made using conventional workflow and heat-press technique as a control and found better internal adaptation for the control group compared to machined crowns, with mean occlusal internal gap for the machined crowns around $200 \mu \mathrm{m}$ and $89 \mu \mathrm{m}$ for the control group.

\section{CONCLUSION}

Within the limitations of this in vitro study, the following conclusions can be drawn:

- There is no statistically significant effect of using different adhesive gap settings $(30,60$ and $90 \mu \mathrm{m})$ on the fracture strength of all-ceramic crowns.

- Varying the cement thickness $(200-360 \mu \mathrm{m})$ does not affect the fracture strength significantly.

- The adhesive gap setting does not reflect the actual cement thickness for the milled crown.

\section{ETHICS APPROVAL AND CONSENT TO PARTI- CIPATE}

Not applicable.

\section{HUMAN AND ANIMAL RIGHTS}

Not applicable. 


\section{CONSENT FOR PUBLICATION}

Not applicable.

\section{AVAILABILITY OF DATA AND MATERIALS}

Not applicable.

\section{FUNDING}

None.

\section{CONFLICT OF INTEREST}

The authors declare no conflict of interest, financial or otherwise.

\section{ACKNOWLEDGEMENTS}

Declared none.

\section{REFERENCES}

[1] Deany IL. Recent advances in ceramics for dentistry. Crit Rev Oral Biol Med 1996; 7(2): 134-43.

[http://dx.doi.org/10.1177/10454411960070020201] [PMID: 8875028]

[2] Morena R, Lockwood PE, Fairhurst CW. Fracture toughness of commercial dental porcelains. Dent Mater 1986; 2(2): 58-62.

[http://dx.doi.org/10.1016/S0109-5641(86)80052-5] [PMID: 3458634]

[3] Kon M, Kawano F, Asaoka K, Matsumoto N. Effect of leucite crystals on the strength of glassy porcelain. Dent Mater J 1994; 13(2): 138-47. [http://dx.doi.org/10.4012/dmj.13.138] [PMID: 7758273]

[4] Albakry M, Guazzato M, Swain MV. Effect of sandblasting, grinding, polishing and glazing on the flexural strength of two pressable allceramic dental materials. J Dent 2004; 32(2): 91-9. [http://dx.doi.org/10.1016/j.jdent.2003.08.006] [PMID: 14749080]

[5] Chen HY, Hickel R, Setcos JC, Kunzelmann KH. Effects of surface finish and fatigue testing on the fracture strength of CAD-CAM and pressed-ceramic crowns. J Prosthet Dent 1999; 82(4): 468-75.

[http://dx.doi.org/10.1016/S0022-3913(99)70036-3] [PMID: 10512968]

[6] Hojjatie B, Anusavice KJ. Three-dimensional finite element analysis of glass-ceramic dental crowns. J Biomech 1990; 23(11): 1157-66. [http://dx.doi.org/10.1016/0021-9290(90)90008-Q] [PMID: 2277050]

[7] Doyle MG, Munoz CA, Goodacre CJ, Friedlander LD, Moore BK. The effect of tooth preparation design on the breaking strength of Dicor crowns: 2. Int J Prosthodont 1990; 3(3): 241-8. [PMID: 2083010]

[8] Doyle MG, Goodacre CJ, Munoz CA, Andres CJ. The effect of tooth preparation design on the breaking strength of Dicor crowns: 3. Int J Prosthodont 1990; 3(4): 327-40 [PMID: 2088368]

[9] Friedlander LD, Munoz CA, Goodacre CJ, Doyle MG, Moore BK. The effect of tooth preparation design on the breaking strength of Dicor crowns: Part 1. Int J Prosthodont 1990; 3(2): 159-68. [PMID: 2133383]

[10] Burke FJ. Fracture resistance of teeth restored with dentin-bonded crowns: the effect of increased tooth preparation. Quintessence Int 1996; 27(2): 115-21.

[PMID: 9063222]

[11] McCormick JT, Rowland W, Shillingburg HTJ Jr, Duncanson MGJ Jr. Effect of luting media on the compressive strengths of two types of allceramic crown. Quintessence Int 1993; 24(6): 405-8. [PMID: 8234646]

[12] Tuntiprawon M, Wilson PR. The effect of cement thickness on the fracture strength of all-ceramic crowns. Aust Dent J 1995; 40(1): $17-21$.

[http://dx.doi.org/10.1111/j.1834-7819.1995.tb05607.x] [PMID: $7710410]$

[13] Scherrer SS, de Rijk WG, Belser UC, Meyer JM. Effect of cement film thickness on the fracture resistance of a machinable glass-ceramic. Dent Mater 1994; 10(3): 172-7.

[http://dx.doi.org/10.1016/0109-5641(94)90028-0] [PMID: 7758860]

[14] Prakki A, Cilli R, Da Costa AU, Gonçalves SE, Mondelli RF, Pereira JC. Effect of resin luting film thickness on fracture resistance of a ceramic cemented to dentin. J Prosthodont 2007; 16(3): 172-8. [http://dx.doi.org/10.1111/j.1532-849X.2006.00168.x] [PMID: 17581178

[15] Rojpaibool T, Leevailoj C. Fracture resistance of lithium disilicate ceramics bonded to enamel or dentin using different resin cement types and film thicknesses. J Prosthodont 2017; 26(2): 141-9. [http://dx.doi.org/10.1111/jopr.12372] [PMID: 26505488]

[16] May LG, Kelly JR, Bottino MA, Hill T. Effects of cement thicknes and bonding on the failure loads of CAD/CAM ceramic crowns: multiphysics FEA modeling and monotonic testing. Dent Mater 2012; 28(8): e99-e109.

[http://dx.doi.org/10.1016/j.dental.2012.04.033] [PMID: 22595741]

[17] Sagsoz NP, Yanıkoglu N, Yanıkoglu N. Evaluation of the fracture resistance of computer-aided design/computer-aided manufacturing monolithic crowns prepared in different cement thicknesses. Niger J Clin Pract 2018; 21(4): 417-22.

[PMID: 29607851]

[18] Hoang LN, Thompson GA, Cho SH, Berzins DW, Ahn KW. Die spacer thickness reproduction for central incisor crown fabrication with combined computer-aided design and 3D printing technology: An in vitro study. J Prosthet Dent 2015; 113(5): 398-404.

[http://dx.doi.org/10.1016/j.prosdent.2014.11.004] [PMID: 25794915]

[19] Faul F, Erdfelder E, Lang AG, Buchner AG. Power 3: A flexible statistical power analysis program for the social, behavioral, and biomedical sciences. Behavior Research Methods Psychonomic Society Inc 2007; 175-91.

[http://dx.doi.org/10.3758/BF03193146]

[20] Zahran M, El-Mowafy O, Tam L, Watson PA, Finer Y. Fracture strength and fatigue resistance of all-ceramic molar crowns manufactured with CAD/CAM technology. J Prosthodont 2008; 17(5): 370-7.

[http://dx.doi.org/10.1111/j.1532-849X.2008.00305.x] [PMID: 18355164]

[21] Neiva G, Yaman P, Dennison JB, Razzoog ME, Lang BR. Resistance to fracture of three all-ceramic systems. J Esthet Dent 1998; 10(2): 60-6.

[http://dx.doi.org/10.1111/j.1708-8240.1998.tb00339.x]

[PMID: 9759024]

[22] Pallis K, Griggs JA, Woody RD, Guillen GE, Miller AW. Fracture resistance of three all-ceramic restorative systems for posterior applications. J Prosthet Dent 2004; 91(6): 561-9.

[http://dx.doi.org/10.1016/j.prosdent.2004.03.001] [PMID: 15211299]

[23] Kelly JR. Clinically relevant approach to failure testing of all-ceramic restorations. J Prosthet Dent 1999; 81(6): 652-61. [http://dx.doi.org/10.1016/S0022-3913(99)70103-4] [PMID 10347352]

[24] Lawn B. Fracture of Brittle Solids. $2^{\text {nd }}$ ed. Cambridge, U.K Cambridge University Press 1993.

[http://dx.doi.org/10.1017/CBO9780511623127]

[25] Kelly JR. Dental ceramics: current thinking and trends. Dent Clin North Am 2004; 48(2): viii-, 513-530. [PMID: 15172614]

[26] Attia A, Kern M. Fracture strength of all-ceramic crowns luted using two bonding methods. J Prosthet Dent 2004; 91(3): 247-52. [http://dx.doi.org/10.1016/j.prosdent.2003.12.005] [PMID: 15060494]

[27] Attia A, Abdelaziz KM, Freitag S, Kern M. Fracture load of composite resin and feldspathic all-ceramic CAD/CAM crowns. J Prosthet Dent 2006; 95(2): 117-23

[http://dx.doi.org/10.1016/j.prosdent.2005.11.014] [PMID: 16473085]

[28] Lampe K, Luthy H, Mörmann W. Fracture load of all-ceramic computer crowns. In: Mormann W, Ed. CAD/CIM in aesthetic dentistry: CEREC 10 Year Anniversary Symposium. Chicago: Quintessence Pub 1996; pp. 463-82.

[29] Kelly JR, Giordano R, Pober R, Cima MJ. Fracture surface analysis of dental ceramics: Clinically failed restorations. Int J Prosthodont 1990; 3(5): 430-40.

[PMID: 2088380]

[30] Zhao YF, Wang HR, Li Y. The effect of tooth preparation design on the CAD/CAM all-ceramic coping crown's fitness. Zhonghua Kou Qiang Yi Xue Za Zhi 2003; 38(5): 330-2 [PMID: 14680576]

31] Bindl A, Mörmann WH. Marginal and internal fit of all-ceramic $\mathrm{CAD} / \mathrm{CAM}$ crown-copings on chamfer preparations. J Oral Rehabil 2005; 32(6): 441-7.

[http://dx.doi.org/10.1111/j.1365-2842.2005.01446.x]

[PMID: 15899023

[32] Prudente MS, Davi LR, Nabbout KO, et al. Influence of scanner, 
powder application, and adjustments on CAD-CAM crown misfit. J Prosthet Dent 2018; 119(3): 377-83.

[http://dx.doi.org/10.1016/j.prosdent.2017.03.024] [PMID: 28689912]

[33] Zimmermann M, Valcanaia A, Neiva G, Mehl A, Fasbinder D. Digital evaluation of the fit of zirconia-reinforced lithium silicate crowns with a new three-dimensional approach. Quintessence Int 2018; 49(1): 9-15. [PMID: 29192293]

[34] Kim J-H, Cho B-H, Lee J-H, et al. Influence of preparation design on fit and ceramic thickness of CEREC 3 partial ceramic crowns after cementation. Acta Odontol Scand 2015; 73(2): 107-13.

[http://dx.doi.org/10.3109/00016357.2014.956145] [PMID: 25299600]

[35] Nakamura T, Dei N, Kojima T, Wakabayashi K. Marginal and internal fit of Cerec 3 CAD/CAM all-ceramic crowns. Int J Prosthodont 2003; 16(3): 244-8.

[PMID: 12854786]

[36] Zeltner M, Sailer I, Mühlemann S, Özcan M, Hämmerle CHF, Benic GI. Randomized controlled within-subject evaluation of digital and conventional workflows for the fabrication of lithium disilicate single crowns. Part III: marginal and internal fit. J Prosthet Dent 2017; 117(3): 354-62.

[http://dx.doi.org/10.1016/j.prosdent.2016.04.028] [PMID: 27677220]

[37] Mou SH, Chai T, Wang JS, Shiau YY. Influence of different convergence angles and tooth preparation heights on the internal adaptation of Cerec crowns. J Prosthet Dent 2002; 87(3): 248-55. [http://dx.doi.org/10.1067/mpr.2002.122011] [PMID: 11941350]

[38] Dauti R, Lilaj B, Heimel P, Moritz A, Schedle A, Cvikl B. Influence of two different cement space settings and three different cement types on the fit of polymer-infiltrated ceramic network material crowns manufactured using a complete digital workflow. Clin Oral Investig 2020; 24(6): 1929-38.

[http://dx.doi.org/10.1007/s00784-019-03053-1] [PMID: 31515700]

[39] Kirsten M, Matta RE, Belli R, et al. Hygroscopic expansion of selfadhesive resin cements and the integrity of all-ceramic crowns. Dent Mater 2018; 34(8): 1102-11. [http://dx.doi.org/10.1016/j.dental.2018.04.008] [PMID: 29709240]

[40] Campagni WV, Preston JD, Reisbick MH. Measurement of paint-on die spacers used for casting relief. J Prosthet Dent 1982; 47(6): 606-11.

[http://dx.doi.org/10.1016/0022-3913(82)90132-9] [PMID: 7047724]

[41] Hasanzade M, Shirani M, Afrashtehfar KI, Naseri P, Alikhasi M. In vivo and in vitro comparison of internal and marginal fit of digital and conventional impressions for full-coverage fixed restorations: A systematic review and meta-analysis J Evid Based Dent Pract 2019; 19(3): 236-54.

[http://dx.doi.org/10.1016/j.jebdp.2019.04.003] [PMID: 31732100]

[42] Rekow ED, Harsono M, Janal M, Thompson VP, Zhang G. Factorial analysis of variables influencing stress in all-ceramic crowns. Dent Mater 2006; 22(2): 125-32.

[http://dx.doi.org/10.1016/j.dental.2005.04.010] [PMID: 16000218]

[43] Pilo R, Cardash HS. In vivo retrospective study of cement thickness under crowns. J Prosthet Dent 1998; 79(6): 621-5.

[http://dx.doi.org/10.1016/S0022-3913(98)70067-8] [PMID: 9627889]

[44] Trindade FZ, Valandro LF, de Jager N, Bottino MA, Kleverlaan CJ. Elastic properties of lithium disilicate versus feldspathic inlays: Effect on the bonding by 3D finite element analysis. J Prosthodont 2018; 27(8): 741-7.

[http://dx.doi.org/10.1111/jopr.12550] [PMID: 27696615]

[45] Charlton DG, Roberts HW, Tiba A. Measurement of select physical and mechanical properties of 3 machinable ceramic materials. Quintessence Int 2008; 39(7): 573-9.

[PMID: 19107265]

[46] Bindl A, Lüthy H, Mörmann WH. Fracture load of CAD/CAMgenerated slot-inlay FPDs. Int J Prosthodont 2003; 16(6): 653-60. [PMID: 14714847]

[47] Thompson JY, Bayne SC, Heymann HO. Mechanical properties of a new mica-based machinable glass ceramic for $\mathrm{CAD} / \mathrm{CAM}$ restorations. J Prosthet Dent 1996; 76(6): 619-23.

[http://dx.doi.org/10.1016/S0022-3913(96)90440-0] [PMID: 8957788]

(C) 2020 Mohammed Zahran.

This is an open access article distributed under the terms of the Creative Commons Attribution 4.0 International Public License (CC-BY 4.0), a copy of which is available at: https://creativecommons.org/licenses/by/4.0/legalcode. This license permits unrestricted use, distribution, and reproduction in any medium, provided the original author and source are credited. 